\title{
THE VETERANS EMERGENCY HOUSING PROGRAM
}

\author{
William Remington $\dagger$
}

\section{Sketch of the Program}

The Veterans Emergency Housing Program-usually alphabetized to VEHPis the one major economic innovation of the Truman Administration. Conceived early in December, I945, with the appointment of Wilson Wyatt as National Housing Expediter, the VEHP was born on December 20, I945, with the issuance of Civilian Production Administration Priorities Regulation 33 which channels building materials into medium- and low-price housing.

With business and the Administration engaged in an almost fervent campaign to liquidate wartime production and distribution controls as rapidly as possible the VEHP siruggled upstream against the trend throughout 1946 , trying to boost the volume of housing construction to record levels, and to ensure that the houses which are built sell or rent at prices which veterans can afford to pay. Data now available indicates that about a million housing units will be started in 1946, if contractors proceed with plans for starting about 75,000 houses late in November and December in spite of uncertainty with respect to materials costs following price decontrol. Completions during the year are estimated at 700,000 . This is a tremendous achievement even though it falls short of the 1946 goal by almost two hundred thousand.

The big question now with respect to the VEHP is one the President did not answer on November 9 when he announced decontrol of almost all prices and wages. With wages and building materials prices free to respond to the pressures of an uncontrolled and highly inflationary market, what happens to the Housing Expediter's 1947 program of 1.5 million starts on medium- and low-priced houses? What happens to construction costs on the hundreds of thousands of houses started this year which are not yet completed? As of November 15, 1946, when this is being written these questions cannot be answered.

It is clear that the VEHP will continue. In his decontrol announcement the President said: "The removal of price ceilings on building materials will obviously necessitate a change in the approach to some of the problems in the housing program. I am asking the Housing Expediter to report to me promptly in this regard. We must continue an aggressive program of building houses and apartments for veterans."

* The reader will bear in mind that changes in this program have been made since this was written, in December, 1946. [The Editor.]

† A.B., 1939, Dartmouth College; M.A., 1940, Columbia University. Economist, Washington, D. C. Formerly Director, Production Division, Office of War Mobilization and Reconversion; and Economist in the Mission for Economic Affairs in London, the War Production Board, the Office of Price Administration and the National Resources Planning Board. 
Housing Expediter Wyatt immediately announced that all VEHP controls except building materials price ceilings will be kept in force, including limitations on nonresidential construction; priorities, allocations and other devices whch channel materials and equipment into veterans' housing; price and rent ceilings on the housing units eligible for assistance under the program; premium payments for increased building materials production; and guaranteed markets and loans for prefabricated housing production. All other controls, orders, regulations and policies put into effect on the initiative of the Housing Expediter will also be retained for the time being. However, it is clear that the end of price control leaves the VEHP as the one major island of government regulation in the midst of a free economy. This fact alone will inevitably require some program modifications.

Although the VEHP will continue, its magnitude and its character will remain uncertain until fundamental decisions are reached with respect to the relative urgency of housing construction and alternative uses for critical materials such as pig iron, steel and lumber. Public and Congressional pressures against government controls over price, production and distribution have been so strong that it will be difficult for the NHA to carry out its responsibilities under the Patman Act. This Act gives housing a prior claim on national economic resources. But until this mandate is reaffirmed by Congress, or by the President, the NHA cannot proceed to use its full powers to stimulate housing construction. Apparently reaffirmation of the Patman Act mandate waits on a clear cut expression by the various interests concerned with respect to relative strength of their desire for decontrol on the one hand, or houses for veterans on the other. At the present time the NHA and CPA materials controls under the VEHP are the only major production and distribution controls which the government is trying to maintain. Strong public awareness of the need for housing construction, and an awareness on the part of materials producers and contractors of the benefits they have gained under the program, may produce mass support for maintenance of these relatively slight inconveniences. On the other hand, the fact that decontrol psychology has swept the country may lead to a reversal of Congressional and Administration sentiment on the urgency of veterans housing.

\section{Background}

Before VJ-Day the wartime construction controls (WPB Order L-4r) were relaxed, not to encourage housing which now has top urgency status, but to permit industrial construction. Six weeks after VJ-Day Washington was overwhelmed with pressure, and L-4I was prematurely revoked. Although available supplies of building materials were low, and although costs and construction time were uncertain, there was a rapid flow of big money into construction. Private construction activity jumped from an annual rate of approximately $\$ 3,072$ million in September, 1945, to an annual rate of about $\$ 4, \mathrm{I} 75$ million in December, 1945 .

Most of the new private construction was commercial and industrial. Business wanted to spend excess profits quickly lest the Government collect them as taxes. 
Many commercial establishments foresaw the prospect of bonanza profits on completion of new construction projects: e.g., redecoration of a night club, addition to a bar, extension of a department store, an addition to a hotel. During the war years a tremendous demand had developed for commercial and industrial facilities because:

(a) Under the strict wartime controls (primarily WPB Order L-4I) construction for less essential purposes had not kept pace with normal depreciation.

(b) Pent-up savings and high levels of current income created an unprecedented demand for hotels, entertainment, trade and other facilities.

Many businesses faced an opportunity to expand their share of the flood volume of consumer expenditures and they were ready and anxious to spend money on construction to share increasingly in the golden tide.

As a result, the relatively small flow of building materials was being largely preempted by commercial and industrial construction. The materials which were left over for housing use tended to go into relatively large houses designed and built for individuals with easy money to spend.

Under these circumstances the Government was forced to take direct action in order to protect veterans who faced the uncertain and difficult job of re-introducing themselves and their families into the American culture which had, for better or for worse, conditioned most of them to living under a roof. This task of finding a niche in the world and a house in the niche is enormously complicated for the average veteran by reason of his relative impotence, financially speaking, as a customer of the construction industry. Customers with excess profits or surtax incomes to spend, commercial enterprises with booming markets to tap, business with expansion plans delayed during the war and maintenance funds accumulated over four years ready to spend-these were the customers of the construction industry whose projects moved briskly ahead. Even the housing that was started was clearly beyond the reach of the ex-GI.

\section{Objectives and Characteristics of Government Program}

The need of veterans to find houses for themselves and their families assumed crisis proportions in late 1945. In spite of the "business as usual" atmosphere created by revocation of $\mathrm{L}-4 \mathrm{I}$, the government moved belatedly to give housing a chance to catch up. This effort involved reinstatement of more drastic controls than would have been necessary if the initial modifications of war restrictions had been made more slowly and with due recognition of the critical nature of the housing shortage.

The government program to protect the veteran who wants to trade his old fox hole for a new civilian model has the following purposes:

(I) To stimulate housing construction to the greatest extent possible without serious interference with other functions of the economy.

(2) To make the housing which is constructed available for veterans.

(3) To ensure that this housing for veterans is provided at a. reasonable cost which veterans can afford to pay. 
When the President appointed Wilson Wyatt as Housing Expediter and asked him to formulate a national emergency program to meet the urgent shortage of housing for veterans, he warned that he wanted no "little plans." The program which was developed on the basis of the President's instruction is definitely not a little one. It is based on the premise that construction of homes for veterans has first priority on the productive resources of the American economy, and it calls for the greatest construction effort in the history of the housing industry.

The magnitude of the VEHP is shown by the following figures:

Non-farm houses started in:

Non-farm houses scheduled to be started under the VEHP in:

$\begin{array}{ccc} & \text { (ooo omitted) } \\ \text { I925 } & 937 \text { (building boom peak) } \\ 1929 & 509 & \\ 1933 & 93 & \\ 1938 & 33^{6} & \\ \text { I941 } & 715 & \\ \text { I945 } & 225 & \\ & & \text { (000 omitted) }\end{array}$

$\begin{array}{lr}1946 \quad \text { total } \\ \text { Conventional } & 73^{8} \\ \text { Conversions } & \text { 100 } \\ \text { Re-use } & 212 \\ \text { Prefabricated } & \text { 100 } \\ \text { Trailers } & 50 \\ 1947 \text { total } & \end{array}$

Conventional 850

Conversions 50

Prefabricated $600^{1}$

The VEHP is primarily a program of assistance to the private home builder. Congress decided against basing a housing program on the kind of low-rent housing for veterans which must be constructed or subsidized by government because private concerns cannot build it at a profit. Consequently, except for re-use of Army barracks and other military installations as temporary housing for veterans, the government is not subsidizing veterans housing but confining its efforts to expediting and facilitating the operations of the private building industry.

These characteristics of the VEHP have been determined by the legislative framework on which it is based. At the end of 1945 when the Housing Expediter was apopinted, he received delegated power from the President under the Second War Powers Act. These powers were broad but they related primarily to the establishment of priorities for production and distribution of materials and equipment.

In addition to normal insurance and loan functions of the FHA, the NHA, through the FPHA, had additional powers under the Lanham Act (r940) and other legislation to construct war housing. Limitations on these powers which confined construction activities to temporary and re-use housing, and limitations on funds,

${ }^{1}$ As of November 15,1946 , it was expected that this figure might be cut in half. 
have limited direct housing construction by the Federal Government during 1946 almost entirely to approximately 200,000 "re-use" units which are being dismantled at military installations and re-erected for veterans' use primarily at colleges and universities.

The Patman Act, the rock on which the VEHP has been founded since it became law on May 22, 1946, gives the Housing Expediter sweeping powers, including the authority to issue directives on matters directly or otherwise related to the VEHP to any of the executive agencies of the Federal Government. Apparently only the President himself is relatively immune from receiving directives under the Patman Act. But again these powers are related primarily to the production, distribution, and use of materials and equipment which are required directly or indirectly for housing purposes.

No provision has been made for direct government subsidy, land purchase, construction of public housing, provision of capital or many other measures which have been used successfully in other countries to construct housing at lower rents and sale prices than an unassisted private construction industry has been able to achieve. VEHP is and must remain (in the absence of the Wagner-Ellender-Taft Act or its equivalent) a program of priority and production assistance to the private builder and materials producer.

The major elements of the VEHP have been as follows:

(I) Curtailing commercial and industrial construction by a limitation order, Civilian Production Administration Order VHP-I.

(2) Stabilizing construction costs by wage controls and by maintaining price controls over building materials.

(3) Stimulating output of building materials by ensuring raw materials for their production by granting priority and price assistance to producers, and by giving premium payments for increased output.

(4) Channeling available supplies of building materials by priority ratings, set asides and other devices into housing units designed to sell at or below $\$ 10,000$ or to rent at $\$ 80.00$ per month or less. This type of assistance is being granted to all types of housing under the program including conversion of existing buildings into units suitable for housing.

(5) Developing a prefabricated house industry by priority assistance on materials and equipment, guaranteed markets, and financial assistance in the form of RFC loans.

(6) Increasing the availability of rental housing because the average veteran does not have the financial resources to invest in a house, particularly at this time when costs are abnormally high.

Many other elements contribute to rounding out the VEHP, such as:

(r) Technical assistance in developing plans and specifications for houses, and in developing and testing new materials. 
(2) Controls over quality of houses constructed under VEHP by FHA inspection during the construction process.

(3) Assistance to contractors and producers of building materials in labor training and recruitment, and arranging loans.

(4) Arrangements for the channeling of government surplus building materials and equipment into both temporary and permanent veterans housing, and to producers of materials.

(5) Limitations on export of building materials.

(6) Increased imports of building materials.

(7) Conservation orders to prevent wasteful or excessive use of the most critical building materials.

(8) Cooperation with the Wage Adjustment Board and the Wage Stabilization Board to secure wage increases necessary for recruiting or maintaining an adequate labor supply for on-site construction or building materials production.

(9) Guaranteed markets for new construction materials.

(Io) Cooperation with the Conciliation Service in the settlement of strikes which hinder construction or materials output.

(ii) Arrangements with the Office of Defense Transportation for securing freight cars to move building materials.

(12) Provision of funds for the construction of access roads into timber lands to increase lumber output.

(13) Support for the President's program of reducing Federal construction ex,penditures to a minimum as part of a general economy policy and to reduce demands by the executive agencies for materials, equipment and skilled labor which are necessary in the VEHP.

In carrying out these diverse aspects of his program the Housing Expediter has not attempted to duplicate or overlap the activities and organization of other Federal agencies which are responsible for policies and programs related directly or indirectly to housing. He has relied on the complete and whole-hearted cooperation of a dozen agencies including:

Civilian Production Administration which has operating responsibility for materials production, conservation, priorities and set-asides, and for non-residential private construction.

Office of Price Administration which has been responsible for building materials pricing.

War Assets Administration which is responsible for matters pertaining to surplus materials and equipment.

Reconstruction Finance Corporation which handles the financial arrangements for premium payments, guaranteed markets, and loans to materials producers and prefabricators. 
The Housing Expediter has for the most part kept his directive powers over other agencies in his pocket, knowing that the unwilling cooperation of his brother bureaucrats is not a firm foundation for a program of this magnitude.

Many veterans' organizations who know of the instances where Mr. Wyatt has negotiated patiently for many weeks or months with another agency (perhaps to arrange financing for a new prefabricated house, or to bring a critically short material under control to ensure the availability of supplies to meet housing requirements), have criticized him for not flexing his legal muscles more frequently and forcing universal acceptance of his viewpoint with a flurry of knockout directives. It is inevitable that on many occasions the NHA and the CPA should differ over such problems as how much pig iron should be diverted to housing uses from automobiles, farm machinery and other essential products. In addition to being a spearhead of decontrol pressure, the CPA has had the partisan responsibility of representing the claims of industries whose material requirements compete with those of the housing program. It is natural that NHA and OPA should have differed over such problems as how high to raise the price of construction grades of lumber as a production incentive. In this type of situation NHA had responsibility to push for the best interest of the housing program. Whether or not pig iron shortages would have unduly handicapped other essential production, and whether or not diversion of logs away from railroad lumber into high profit construction grades would severely limit freight car production are questions which should not be answered without detailed knowledge of facts and impartial economic perspective which do not and should not exist in the agency responsible for construction of houses.

The Expediter has been thoroughly aware of the partisan nature of his responsibilities and he has been careful wherever possible to work out differences in judgment between himself and other agencies by negotiation. Cases involving irreconcilable disagreement as to the relative importance of housing and some other essential activity have inevitably been referred to higher authority. An agency receiving an unwelcome Housing Expediter directive would; of course, appeal upstairs in any case. Under these circumstances directive power has been important only in two respects:

I. It has served as an indication to all agencies that the Congress and the Administration wish the VEHP to have, within reason, a top priority claim on national economic resources; and

2. The fact that the Expediter has directive powers in his pocket has often helped the head of another agency to appreciate the cogency of the Expediter's arguments.

It is abundantly clear that directive powers in the hands of any one executive agency does not make for amity within the official family. Those few agencies which have been on the receiving end of a Wyatt directive have been conspicuously unenthusiastic about being overruled by a coordinate agency. Congress should not be urged to grant such authority indiscriminately. 


\section{Progress}

The measures taken by the Government to facilitate construction of veterans' housing (which are described individually in later sections of this article) met with striking success during 1946. It is estimated that about 700,000 housing units will be completed during the year. By the end of October almost 900,000 housing units had been started and it was expected that by the end of December more than $1,000,000$ units will have been started in 1946 , unless uncertainty over price advances following decontrol leads contractors to defer a substantial proportion of the approximately 75,000 starts scheduled for late November and December. This compares with the original goal of $x, 200,000$ units to be started in $x 946$, and a r925 peak of 937,000 starts.

The reasons why the goal could not be met in full include:

(a) Delay in the passage of the Patman Act. When the Housing Expediter announced a goal of 1.2 million houses for 1946 in February, he expected to have legislative authority and funds available for premium payments and other actions to promote production of building materials during ten months of the year. By the time the Act was approved, near the end of May, only seven months remained.

(b) Strikes in the steel industry during February and in the coal industry during April and May cost the nation approximately is per cent of the year's output of pig iron and steel. Shortages of pig iron for cast iron soil pipe, bath tubs, radiation and furnaces, and shortages of steel for prefabricated houses, windows, bath tubs and plumbing, nails and other essential items have been partly responsible for persuading builders to postpone new starts.

(c) The high rate of non-residential construction which the Government authorized in order to protect public health and welfare and to ensure continuation of essential economic activities. During the first six months of the program a tremendous volume of construction was approved as essential which would be disapproved under the more uniform and strict standards of essentiality currently in effect.

(d) The high level of construction costs and the threat of an inflationary boom and bust have definitely deterred a great many builders and buyers from investing funds in housing construction. The price control holiday during July discouraged construction significantly.

(e) Certain agencies whose cooperation is essential to the success of the VEHP have differed with the National Housing Agency as to the urgency of the housing program and the mandates of the Patman Act. Consequently, they have not been willing to divert resources from other industries to housing to the extent requested by the Expediter.

For the most part contractors who started housing construction during the early part of the year were not able to meet construction time schedules. The construction cycle for a house, which in normal times is between three and four months, length- 
ened out to almost seven months. With contractors unable to secure materials to complete houses expeditiously and economically, by the middle of the summer the rate of new construction starts was falling below the rate required to meet the 1946 goal. This was recognized by the Housing Expediter and in August a series of actions were taken in coperation with the Civilian Production Administration to increase the proportion of building material supplies available for housing. These emergency actions increased the number of materials subject to priorities, and sharply increased set asides of critical materials for housing use (the priority and set aside regulations will be described in a later section of this article). As a result it was possible for contractors to complete a large portion of the houses which were started earlier in the year. This improvement in the ability of contractors to finish houses already started probably prevented a serious decline in new construction activity.

The following table shows estimates of the housing units started and completed between January $\mathrm{I}$ and October 3r, r946:

\begin{tabular}{|c|c|c|}
\hline 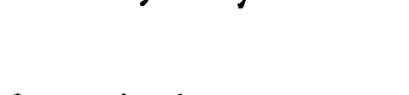 & $\begin{array}{c}1 / 4 / 46-10 / 3 x / 46 \\
\text { Starts }\end{array}$ & $\begin{array}{r}\mathrm{I} / \mathrm{I} / 46-\mathrm{ro} / 3 \mathrm{3} / 46 \\
\text { Completions }\end{array}$ \\
\hline Conventional .... & .... 550,000 & $3^{10,000}$ \\
\hline Conversions ..... & . 50,000 & 50,000 \\
\hline Temporary re-use ${ }^{2}$ & . $x 90,000$ & 70,000 \\
\hline Prefabricated ....... & ‥ 30,000 & 30,000 \\
\hline Trailers $\ldots \ldots \ldots \ldots \ldots \ldots$ & ... 35,000 & 30,000 \\
\hline Local Emergency Housing ${ }^{3}$ & 30,000 & 10,000 \\
\hline Total & 885,000 & 500,000 \\
\hline
\end{tabular}

Description of the Major Elements in the VEHP

\section{Civilian Production Administration Order VHP-I.}

On March 26, r946, the Civilian Production Administration issued a construction limitation order called Veterans' Housing Program Order No. I (VHP-I), in order to reduce the diversion of critical resources, equipment and skilled labor into nonresidential construction.

In January, I946, construction activity was as follows:

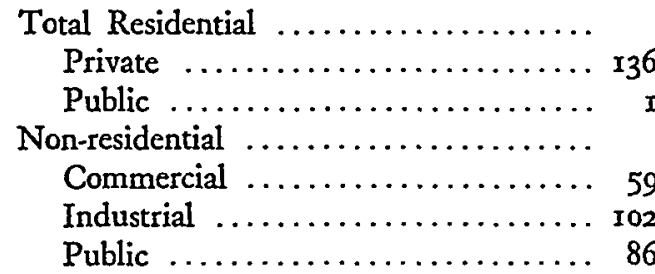

(In millions of dollars)

137

247

(Including highways, military and naval construction, sewer and water systems, non-residential structures, etc.)

\footnotetext{
3 Temporary construction by federal government for educational institutions and state and local govcrnments, involving re-use of Army, Navy and other federal war-time facilities.

${ }^{8} \mathrm{New}$ permanent construction by local governments and educational institutions, involving the re-use of federal facilities, use of surplus materials, and conversion.
} 
The large absorption of building materials by non-residential construction was expected to increase sharply during the year. It was estimated that the best efforts of the construction industry combined with rapid acceleration in output of building materials would bring total volume of new construction activity in the continental United States close to a total of \$1o billion for 1946 . Of this total VEHP is expected to constitute a minimum of $\$ 3.6$ billion. After taking account of the anticipated economies in federal, state and local construction programs, it was expected that minimum construction put in place by the government would total about \$r.9 billion. Farm construction was expected to be $\$ 4$ billion and public utility construction $\$ .8$ billion. Consequently, if the VEHP goals were to be met, it was obvious that private non-residential construction must be held to approximately $\$ 3.2$ billion in 1946 . These estimates were rough, but they have proved approximately correct.

Between the relaxation of $\mathrm{L}-4 \mathrm{I}$ and the end of March, 1946 , private non-residential projects were started which were expected to involve construction valued at approximately \$2.I billion during 1946. This meant that new projects started during the last nine months of the year must be held to a value put in place during 1946 of about $\$ 1.2$ billion. The output of building materials and the capacity of the construction industry imposed rigid limitations on the total volume of construction which could be undertaken.

VHP-I provided that after March 26, I946, no one could start construction of a structure outside the VEHP without prior approval of the Civilian Production Administration. Exemptions were made for maintenance and repair; small projects; reconstruction of damage caused by fire, flood, wind, etc., under certain circumstances; minimum work necessary to prevent more damage to a building or its contents damaged by fire, flood, wind, etc.; and construction by the Army, Navy and Veterans Administration. Construction of utility lines, railroads, highways, and other work not involving the erection of a structure as defined in the Civilian Production Administration order were not subject to control on the grounds that such construction does not interfere with the availability of the kinds of materials, equipment, and labor needed for housing construction.

The administration of VHP-I is handled jointly by the Civilian Production Administration and the National Housing Agency. Applications to build under VHP-r are received by construction field offices of the Civilian Production Administration and reviewed by a Civilian Production Administration district construction committee. An NHA observer sitting with the committee can appeal a committee decision to higher authority. Approval of projects valued at over $\$ \mathrm{r}$ million must be approved by a CPA-NHA Committee in Washington in order to ensure uniformity of approval criteria throughout the country. Provided with war-time experience on construction limitation and processing of applications, the administrators of VPH-r had the foresight to keep a record of each application on a machine punch card. For the first time, it has become a simple matter to prepare a factual reply to a 
Congressman who protests that the Government is discriminating against his constituents.

In view of the urgent need for reducing commercial and industrial construction in order to ensure the availability of resources for housing construction, more or less strict standards of essentiality have been applied to the review of applications under VHP-r. However, it is obvious that some commercial and industrial construction must proceed in the interest of public health and welfare as well as national economic well being so the following criteria were developed as a basis for deciding on applications for permission to build.

Construction can be approved under VHP-r on grounds that approval:

I. Is necessary to avoid exceedingly severe hardship;

2. Is essential to maintain public, health and safety;

3. Will cause no impact whatsoever on VEHP;

4. Will increase production of critical materials or products listed by CPA;

5. Is essential to increase food production or preservation;

.6. Will provide educational facilities needed by veterans;

7. Is ersential to protect property and resources;

8. Will provide community facilities necessary for new residential areas developed under VEHP.

During the first weeks of operations under VEHP-I a relatively large volume of approvals was necessary on grounds of hardship. Many contractors had invested large sums of money, and procured materials for construction which was just about to start when VHP-I was issued. In many cases considerations of equity and financial hardship persuaded CPA to approve relatively non-essential projects. During April and May authorizations under VHP-I averaged \$I45 million a week. On May 3 I stricter standards of essentiality were adopted, and a ceiling was placed on authorizations which reduced the average to about $\$ 49$ million weekly. The gains from this reduction in non-residential construction could not be realized immediately because of time lags in starting projects and because many of the authorized projects scheduled to start in 1946 are not scheduled for completion until 1947 and later.

Estimates made in August indicated that put in place activity during 1946 on all projects approved under VHP-I between April and August was expected to exceed a billion dollars. It was obvious that the high rate of private non-residential construction was making it impossible for the VEHP to reach its goal. The supply of building materials and the capacity of the building industry simply was not adequate to sustain this volume of non-residential construction and at the same time build an adequate number of houses for veterans. Consequently, at the end of August a drastic cut was made in authorizations under VHP-I. The rate of approval was slashed from $\$ 49$ million a week to approximately $\$ 35$ million. During September actual authorizations fell I5 to 20 per cent below the target level of $\$ 35$ million a week. For the first time all non-essential construction was disapproved; some rather 
essential projects undoubtedly were thrown out with the rest. Although the effect on demands of the construction industry for building materials could not be realized immediately, it is expected that the impact of this reduction will be effective before the end of 1946 .

In September residential construction outstripped commercial, industrial, and governmental non-residential building construction for the firft time since ra4r. Home construction during the month reached an annual rate of $\$ 4.6$ billion as compared with $\$ 4.4$ billion for non-residential structures. This fundamental change in the relationship of housing to non-housing construction is due as much to the effects of VHP-I as it was to the rapidly increasing activity of the housing contractors. Although the tremendous volume of commercial and industrial construction started prior to VHP-I carried the gross amount of construction activities in this category up month by month until August, and although the effects of the order did not produce an absolute decline in non-residential construction until six months after it was imposed, VHP-I obviously prevented an acceleration of commercial and industrial activities which would have made the VEHP impossible.

\section{Stabilization.}

One of the major objectives of the VEHP is to ensure that the houses which are built are available for sale or rent to veterans at prices which they can afford to pay. The effort to keep the cost of housing down has had three major aspects:

(a) Price controls over building materials-administered by OPA.

(b) Direct wage controls for on-site construction labor-administered by the Wage Adjustment Board.

(c) Limiting the sale price or monthly rental of housing which can be built under the program to $\$$ ro,000 and $\$ 80$ per month respectively-administered by the NHA.

After the President's decontrol decision on November 9, only the last remained. From now on major reliance must be placed on increasing supply to the point where supply-demand relationships compel a break in material and construction costs. An unplanned falling off in housing starts may, to his great regret, assist the Housing Expediter in bringing supply and demand into balance.

In a sense price decontrol has simplified the Expediter's problems at the same time that it largely wrecks the stabilization aspects of his program and threaten to reduce construction starts.

In applying stabilization controls the Housing Expediter has been faced with a critical problem which decontrol has largely lifted out of his hands-the problem of reconciling two apparently contradictory courses of action. It would seem that any increase in the price of building material, wages, or in contractors' profits, would tend to boost the cost of housing. Yet one of the major factors tending to drive construction costs up is delay during the construction process-delay in procurement of materials primarily, and also delay in securing equipment. Inefficient labor and 
contractor management also drives costs up. In order to push total cost down it is necessary to pay what it costs to get an adequate supply of building materials, to recruit efficient labor, and secure adequate contracting organizations in the field of housing construction. The problem has been to find the proverbial and illusive happy medium-the point where the additional cost of increased efficiency results in a minimum total cost of construction at a high enough level of activity to produce 1.2 million starts in 1946 . Practically speaking the problem can be stated thus:

(a) What price level has been necessary on each building material to bring out production adequate to sustain the program with enough supplies left over for other essential purposes.

(b) What wage rates have been necessary to attract the requisite quantities of labor.

(c) What are the levels of sales price or rental price on a finished house which will attract contractors and give them a reasonable expectation of making a satisfactory profit.

This approach to the problem is based upon the rough but reasonable assumption that housing construction at the programmed level can proceed most efficiently and economically if, and only if, adequate supplies of building materials, labor, and contracting organizations are secured. However, as things stand, the Expediter can and must wash his hands of these considerations as far as materials pricing and wage rates are concerned. After November 9 , I946, his only way of affecting materials prices and wages is via the back door of increasing supply (and, of course, by reducing demand through a cutback in VEHP-a step he may have to take).

Effects of Price Decontrol. During the week when the President was debating his decontrol decision, the Housing Expediter appeared before a committee of the American Legion and stated that removal of price controls would create great hazards for the VEHP. But there were larger issues at stake than the low cost of building materials. Regardless of the effect on housing construction, the Administration had to choose decontrol. The President said in his statement of November 9 what had been abundantly clear for some weeks: Price controls had broken down. In anticipation of higher prices through the end of price ceilings or otherwise, and in some cases deliberately to force decontrol, many sellers had begun to withhold goods from the controlled market. The inability of the Federal Government to act in the face of decontrol fever was so clear and so noticeable that the fever spread rapidly. Regardless of the other substantive issues, it became obvious that price ceilings no longer had even the passive support of the indlustries governed by them. The whole structure began to crack.

These factors which forced general decontrol were apparent among some producers of building materials but not to the same marked extent as in other sectors of the economy. Legally, it would have been possible to keep price ceilings over building materials in the face of general decontrol, and administratively it probably 
would have been possible to force building materials producers to observe ceiling prices if they had been retained to protect the VEHP. But such a course of action would have had most unfortunate consequences as the President made clear on November 9. He said: "I wish that it were possible to keep effective price controls on building materials in furtherance of the veterans emergency housing program, under which we have seen an unprecedented acceleration both of home building and of the production of building materials. But price control on building alone, with no price control on products competing for the same raw materials, would drive these materials away from housing and defeat the objectives of the program."

If price control had been retained on construction lumber, for example, but not on railroad lumber and boxing and crating, all the king's horses and all the king's men could not have compelled the production of enough construction lumber. With price controls on housing type castings such as furnace parts, pig iron would have been diverted into such items as refrigerator and transportation castings and other decontrolled foundry products.

It is far too early to determine the effects of decontrol on building materials prices. However, the best available information on supply, demand and historical price policies in the materials industries point toward the following rough hypotheses:

I. Supply is catching up with demand for a few building materials such as: brick, structural clay tile, building blocks, and common grades of lumber. Although prices on such items may rise somewhat where there are local shortage situations, it is probable that competition among producers will hold prices generally stable and perhaps force a decline within a few months. Already in some areas an increase in producers inventories indicates the imminent end of the current sellers market.

2. Price leadership in some building materials industries is perhaps stronger than federal price controls. Although the price of gypsum board and lath, ply. wood and other building boards may go up due to increases in cost, the strong historical trend toward price administration within these industries themselves will probably prevent a runaway inflation.

3. There may be sharp and sustained price increases for many critical building materials where current demand considerably exceeds supply: e.g., cast iron soil pipe; hardwood flooring; millwork, including doors; the better grades of lumber; exterior paint; some plumbing supplies; etc.

Sharp increases in building materials prices will have a serious effect on several hundred thousand housing units which are currently under construction. A contractor who is trying to finish a job which is already under way is in no position to be coy and go on a buyer's strike against higher materials prices. It is the vigorous demand for materials to finish partially completed projects which will have the most dangerous but shortrun effect on prices, and the increase in prices will have a sharp effect on the cost of construction. It is possible that the sale and rental ceilings will 
be broken on much of the housing construction which was underway at the time of decontrol. Financing arrangements on these units, and saleability, may be seriously affected in many cases.

Price increases following the elimination of price ceilings can be expected to slow down the rate of new housing starts. With a reasonable prospect of lower materials costs and more certain delivery after the initial effects of decontrol have worn off, many contractors who had planned to start a housing job in the near future will sit tight to see what happens because there are distinct signs of buyer resistance to high priced housing and because the market may break before a house started now could be completed. Not only are veterans showing an increasing reluctance to buy or build at what may be the peak of construction costs, but realtors in many cities are reporting signs of softening in the market for existing houses. If the only way prices can go from here is down, no builder wants to put his money into real property or building materials at the top of the roller coaster.

The effects of decontrol may not be wholly bad. There are some materials in short supply, such as softwood flooring, where producers have claimed that the only barrier to increased production has been price. With the end of price control the producers will certainly do their utmost to prove the truth of their earlier contentions by producing flooring at record levels. In so far as there is an increased availability of flooring, or any material where price factors have discouraged production or encouraged withholding, and in so far as price increases on building materials attract producers of other products to produce housing items, there will be an increased supply of materials for housing. Although these factors are not expected to be important, there may be small increases in supply which will make it possible for some contractors to reduce final costs by securing continuity in the construction process.

Remaining Stabilization Controls. The major controls over the cost of housing which remain in the Expediter's hands are indirect. He can depress costs somewhat by increasing the supply of materials and labor. He can decrease demand by cutting non-residential construction still further (a theoretical possibility only), or by reducing the magnitude of the VEHP. However, one more or less direct control remains. It is direct in the sense that it puts a ceiling on the sales price or rent level of housing units constructed under VEHP. It is indirect in that it does not lower construction costs. This control is the $\$ 10,000$ and $\$ 80$ per month limits on sales price or rental level respectively. A house designed to sell or rent above these ceilings cannot qualify under the program, and of course it cannot be built outside the program except in the unlikely event that approval is secured under VHP-x.

As a matter of public policy the pricing controls on new housing operate before the construction start is made rather than after completion. No contractor would build if the price for which he could sell the finished house were to be established by a government agency after completion. When a contractor applies for permission to construct a house, he submits his plans to the FHA. A house designed to sell at 
more than $\$ 10,000$, including the cost of land and contractor fees, or to rent at over $\$ 80$ per month, cannot be approved.

In so far as building costs go up far enough following decontrol so that the FHA recognizes the fact, enforcement of this rule will force a downgrading of the quality of the highest cost houses which can qualify under the program. An upward movement of costs may carry many housing units which are already under construction over the ceilings, but such cases will be beyond FHA control.

Likewise, the ceilings will not restrain an upward movement in the average price or rental of new houses to be started under VEHP. As costs go up the house which could have been built for $\$ 6,500$ in early 1946 may cost $\$ 7,500$ or more in early 1947 .

The NHA has required the FHA to hold back on high cost units in screening and approving $\mathrm{HH}$ applications so that the bulk of the program would be at or below a sales price of $\$ 6,500$ or an equivalent rental. During the summer when applications for assistance fell below the rate of approvals required to reach the programmed goals, this effort became completely ineffective.

The Expediter continues to offer technical assistance to contractors in preparing plans for housing units which can be constructed at a minimum cost. Although housing quality may be increased in this way, no significant reduction in construction cost can be expected to result from this aspect of the program.

\section{Building Materials Production.}

During the first ten months of 1946 there has been a dramatic increase in the output of building materials. The Department of Commerce index of building materials production, including 16 major materials, shows that output in August, 1946, was 89 per cent higher than December, 1945, and about 60 per cent above the monthly average for 1939. Average daily output in September continued the same strong upwaid trend, although for some materials total output for the month was down because there were to per cent fewer working days than in August. Preliminary figures for October indicated that new post-war production records were attained for most materials.

Increases for many individual materials were spectacular. In the first ten months of 1946 output of wire nails and staples increased 180 per cent, from 25,000 tons in January to over 70,000 tons in October; sink production in October was 97 per cent above January; hardwood flooring, cast iron soil pipe, cement, and bath tubs showed gains of between 70 and 80 per cent from January to October; like increases occurred in the production of common and face brick, cast iron radiation and warm air furnaces between January and September; structural clay tile and convectors increased $6_{5}$ and 50 per cent, respectively, from January to September; five materialsgypsum board and lath, lavatories, clay sewer pipe, softwood plywood and water closet bowls-rose 30 to 50 per cent from January to October; and only 2 major building materials, asphalt roofing and other building boards, rose less than 20 per cent due largely to strikes in the plants of large producers. 
In spite of the high levels of building materials output, the materials requirements of the VEHP during 1946 will tot be met. Even though actual housing starts will fall more than 15 per cent below the program, material supplies will not be sufficient for speedy completion of housing units under way. Accumulated deficits of supply carried over from the early months of the year are creating local shortages of such materials as brick, even though the current rate of production has possibly reached the current level of requirements for houses and non-residential projects which have been and are being started. For other materials such as millwork and cast iron soil pipe, the gap between 1946 requirements and supply is estimated to be as high as 30 per cent of requirements.

During 1947 the rate of production of most building materials will reach or exceed the estimated level of 1947 requirements based on the assumption that controls over non-residential construction continue. However, accumulated deficits carried over from 1946, and which must be filled if construction now under way is to be completed, may extend the duration of the expected shortages. Certain other building materials, such as hardwood flooring, are expected to be critically short throughout 1947 .

These speculations about supply and requirements relationships are based on the assumption that any falling off in housing construction following decontrol will be temporary. If the costs of building materials go up sufficiently so that a large number of contractors postpone housing construction, demand will come into balance with supply as soon as a substantial number of the housing units which are now under way are completed.

The major techniques which have been used to stimulate increased output of building materials are as follows:

(a) Price Increases.

One of the major means adopted by the National Housing Agency to stimulate increased output of building materials during the first months of the VEHP was to secure increases in the ceiling prices of building materials where it was found that ceilings were inadequate to induce producers to increase output. During the first nine months of 1946 approximately 200 price increases for building materials were authorized by the Office of Price Administration. Most of these actions were taken after negotiation with the National Housing Agency or on the initiative of the National Housing Agency or the Civilian Production Administration. The use of price as a means of stimulating increases in the output of materials began shortly after VJ-Day when the Civilian Production Administration, the Office of Price Administration and other government agencies met to take joint action to stimulate output of building materials.

The index of building materials prices prepared by the Bureau of Labor Statistics shows a movement from I29.5 in August, I944, to 131.5 in August, 1945. The same index shows a marked increase during the fall of 1945 and rapid advances during the first eight months of 1946 , reaching 148.2 in August, 1946. The average prices of building materials between 1935 and 1939 equals 100 on this index. 
The advance of the building materials price index is not due solely to the use of price by the National Housing Agency and the Office of Price Administration as an incentive for increasing building materials output. A significant proportion of the price increases in building materials were required by the normal pricing standards of the OPA in order to meet increased costs of production due to higher wage rates and increased costs of basic materials. However, regardless of the basis on which they were authorized, the bulk of the price increases on building materials during the last months of 1945 and the first quarters of 1946 had the effect of increasing building materials output or preventing declines that otherwise would have occurred. For example, price increases on construction grades of plywood were granted in order to make it profitable for plywood producers to discontinue output of non-construction grades, convert their machinery and use their peeler logs for the types of plywood urgently required in housing construction. Producers of cast iron soil pipe were granted sizable price increases in order to permit payment of higher wages required to attract labor into unpleasant foundry occupations. Producers of certain types of lumber were given price increases in order to cover the additional costs of equipment, labor, road construction and transportation required to cut logs from relatively inaccessible timber stands.

(b) Priority Assistance.

A second major means of stimulating materials output which was used during the last months of 2945 and which is used extensively under VEHP is priority assistance to building materials producers for the procurement of capital equipment and raw materials.

The Civilian Production Administration has placed many building materials on its critical list, making producers eligible for various types of special assistance. For example, producers of such building materials as brick, hardware, cast iron soil pipe, clay sewer pipe, and over a dozen other materials, have been granted permission to apply to the Civilian Production Administration for priority ratings to facilitate procurement of equipment necessary for the expansion of output. Expansion of capacity under this rating assistance program has contributed significantly to boosting output of materials this year.

One of the most important CPA priorities programs during 1946 has been the preference granted to producers of critical housing products for the procurement of steel and pig iron. Effective June 12, x946, CPA issued Direction 12 to M-2r which provided for certification and preferential treatment by mills and warehouses of orders for steel needed for housing items, such as bath tubs, lavatories, convector radiation, and steel registers and grilles. Assistance was also granted to producers of certain items of farm equipment needed to harvest this year's crop, and brake shoes for railroad rolling stock. Manufacturers of these critical items could certify orders which they had placed on a steel mill after January I, 1946, on which delivery was promised prior to October I, 1946. Manufacturers of these items were also allowed to certify their own orders on warehouses. If the receipts of steel resulting 
from these certifications were not adequate, the manufacturers could apply to CPA for special assistance. Steel mills and warehouses were directed to honor certifications in preference to all other orders for the same steel product classifications except orders rated AAA or those placed by special directive from CPA.

In the fourth quarter of 1946 the manufacture of some items needed for housing still had to be expanded. The CPA issued Direction 18 to PR-28 to replace Direction I2 to $M-2 I$ in the fourth quarter. Under this direction, assistance in obtaining steel is limited to a select group of thirteen critical housing items. Such assistance is given through the assignment of ratings by CPA to orders for steel which will be used in making these housing items. Direction I 8 to PR-28 will probably be extended into the first quarter of 1947 and four new groups of housing items, including steel door frames, window sash and frames of certain types and jackets or casings for warm air furnaces and low pressure boilers, have been added to the list of items eligible_for assistance. In addition, certain size and color limitations have been placed on a number of items such as bath tubs and lavatories.

The critical shortage of pig iron made it necessary to extend assistance to manufacturers similar to that given users of steel. Late in June, CPA issued Direction I3 to M-2I which channeled pig iron into certain items needed for the housing program, to certain items of farm machinery needed to harvest this year's crops and to brake shoes. Under this direction, CPA issued a certified purchase authority to individual applicants who produce the specified items. The purchase authority covered a definite tonnage of pig iron to be received by the individual applicant during a given month from designated blast furnaces. Assistance for obtaining pig iron was continued under Direction 13 to $M-21$ in the fourth quarter of 1946 , but the list of items covered was somewhat altered and agricultural equipment items were stricken from the list. Iron castings required in the manufacture of certain items for the housing program were placed under Direction 18 to PR-28, just as was steel. However, pig iron required to produce these castings was still covered by Direction I3 to M-2I. This program is expected to continue in the first quarter of $x 947$ because of the urgency of housing requirements for building products made out of pig iron.

(c) Production Orders and Directives.

The Civilian Production Administration, in cooperation with the Housing Expediter, has used its authority to issue various types of production orders and directives under the Second War Powers Act to stimulate the production of critical building materials.

The types of action have differed widely from case to case. For example, gypsum board and lath has been a critical building material throughout 1946. At the beginning of the year it became apparent that the major bottleneck which prevented the gypsum board and lath industry from operating at capacity was the shortage of paper liner which is used as exterior facing on gypsum board. Although the larger proportion of the paper liner requirements of the gypsum board industry is met by 
captive paper producing plants, it has been necessary during 1946 for the gypsum industry to secure approximately ten or eleven thousand tons of paper liner a month from individual paper producers.

Unfortunately pulp and paper mills have shown great reluctance to produce paper liner. The gypsum board and lath industry is not considered as a potential long-run market for the paper and pulp industry because of the strong tendency toward pro. curement of paper liner from captive plants. Independent producers of paper liner regard every pound of pulp or pulp diverted from container board and other paper products to paper liner as a serious loss to potential long-run customers and trade relationships with them.

In order to protect the urgent requirement of VEHP the Civilian Production Administration issued shipping directives to the potential producers of paper liner requiring them to ship the necessary quantities to the gypsum board and lath industry. To make the directives generally effective it was ultimately necessary to work out complex arrangements with the pulp and paper industry whereby paper producers who were technologically unable to turn out liner produced some paper for the companies which could use their machinery for liner. This paper was used by the latter companies to meet the requirements of regular customers. In this fashion the impact of paper liner directives was spread with greater equity among all producers in the industry and the concerns capable of turning out liner were not put at a serious competitive disadvantage in relation to the others. On this basis, compliance with CPA directives improved but it was not until the introduction of premium payments that paper liner supplies reached a satisfactory level.

The type of action which can be taken to increase the supply of critical materials depends largely on the structure of the industry concerned. The Civilian Production Administration orders and directives which have been issued to increase the output of critical lumber products indicate how exactly controls must be tailored to fit the pattern of organization of the industry concerned.

Millwork is one of the most critical of the building materials. The present CPA lumber order includes several provisions designed to increase millwork output. For example, millwork manufacturers are given the right to place "certified" orders with sawmills for "shop grade" lumber (high grade knot free lumber from which millwork can best be made) each month up to II per cent of their r940 consumption. "Certified" orders have priority over other orders placed at the sawmill. Sawmills are required to set aside certain types of lumber, including western pine and fir shop grades, for sale only to manufacturers of millwork (and other specified critical products) or their suppliers on certified or rated orders. Without these complex provisions which establish the volume of raw materials which millwork producers may procure, and which direct sawmills to set aside for millwork producers the raw materials which they need, priority assistance would not be practical. Sawmills would refuse to accept priority orders from millwork producers on grounds that orders were inflated beyond real requirements. (To a certain extent this claim 
would probably be accurate.) Without uniform set-asides, each sawmill owner would protest that he was receiving an undue proportion of the rated demand and consequently that his regular customers with unrated orders were being discriminated against.

The Civilian Production Administration lumber order also establishes a system whereby manufacturers of hardwood flooring purchase hardwood lumber under a quota system. It is also required that certain types of hardwood lumber be sold exclusively for the manufacture of flooring. This type of preference is necessary in order to prevent diversion of the raw material for flooring to competing products such as furniture.

Production controls over softwood plywood afford another illustration of the variety of production orders and directives which have been issued by the Civilian Production Administration to stimulate the output of critical materials. Producers of softwood plywood are compelled to produce approximately 50 per cent of their monthly output in construction grades. Furthermore, not more than 20 per cent may be of an exterior type.

At the request of the National Housing Agency, the Civilian Production Administration has issued an order designed to increase the output of housing grades of cast iron soil pipe. The order specifies the weights and sizes of pipe which may be produced. Weight specifications prohibit the production of the normal heavy grades of pipe which require large quantities of pig iron. They compel return to light weight victory grades which were used during the war. Size specifications require that approximately 93 per cent of all output of cast iron soil pipe be in the small sizes required by the VEHP. Only 7 per cent of the total output can be in the larger sizes which are used primarily for non-residential purposes.

(d) Informal Production Orders.

In many cases the National Housing Agency and the Civilian Production Administration have reached informal agreements with producers of critical building materials, and producers of basic materials needed for housing items, concerning increases in output or increases in shipments for housing purposes. A notable illustration of this type of action is construction nails. Shortages of nails have been one of the most serious obstacles to housing construction in many areas of the country. In May, 1946, agreement was reached between the National Housing Agency, the Civilian Production Administration, the Office of Price Administration and nail producers whereby the producers agreed to accept monthly production goals established by the Civilian Production Administration, and the Office of Price Administration agreed to increase the price of nails as an incentive to divert wire from alternative products such as fencing which were more profitable under existing price ceilings. This agreement was carried out on the government side and has been partly implemented by nail producers even though no formal order or regulation has required them to carry out their side of the bargain. 
(e) Assistance in Labor Recruitment.

As a result of agreement between the National Housing Agency, Civilian Production Administration and the Department of Labor, special efforts have been made by the U.S. Employment Service to recruit labor for industries which produce materials and products which are certified as critical by the Civilian Production Administration. Special labor recruitment programs have also been conducted to secure adequate quantities of on-site construction labor.

(f) Premium Payments.

Section II of the Veterans' Emergency Housing Act of 1946 created premium payments as a tool for increasing production of building materials without generally increasing prices. Basically premium payments are a device for evoking marginal production without incurring a general price increase to cover the high incremental costs of marginal production. They are used to give a producer a financial incentive to incur the costs involved in boosting his output above the maximum rate which he would otherwise achieve.

For this purpose Section II authorizes a maximum of $\$ 400,000,000$ to be spent in premium payments by the Housing Expediter subject to the following statutory standards which government lawyers have been puzzling about ever since the Act was passed:

(i) That such payments be of a temporary nature,

(ii) That wherever feasible, the premium payments should be at a uniform rate within an industry,

(iii) That where such payments are applied to a new material, that material should be tested for sound quality,

(iv) That emphasis be placed on avoiding economic dislocations or adverse effects upon established business,

(v) That in the case of new producers (except of new type materials) premium payments should not exceed 50 per cent of the total value of the product,

(vi) That the aggregate value of units to which premium payments are applied should not exceed 30 per cent of the value product of all building materials, and

(vii) That the average rate of premium payments shall not exceed 25 per cent of the value of the units of production to which applied.

When a premium payment plan is instituted for a building material, each producer who wishes to participate can calculate and report his "quota" production on the basis specified in the plan. This "quota" represents, for purposes of the plan, the level of output which the producer could or would attain without premium payment assistance. On any output in excess of the quota, or a stated percentage of the quota, the producer receives a premium payment at the rate specified in the plan. Generally speaking "quotas" have been set at levels which will insure that 
producers will receive a significant volume of payments to cover the relatively high costs of increasing output even slightly above the highest levels attained in the earlier months of 1946 .

Between the first of June and the first of November, premium payment plans were inaugurated for eleven building materials: Structural clay, softwood plywood, merchant gypsum liner, standing timber, convectors, Northern hardwood flooring, cast iron soil pipe, pig iron, sand lime brick, and nails. During the month of November, plans for many additional materials were in various stages of development.

In developing each of these, two considerations were dominant: first, administrative simplicity; and second, ensuring that premium payments should hit directly at the major bottleneck in a particular industry.

Because of the first consideration, quotas have been established on an "historical" basis-as a percentage of production in some specific period or periods rather than on a basis of plant capacity which is difficult to determine accurately; quotas and payment claims are worked out by the producer himself and certified as true by him; and payments are made at uniform rates rather than progressive rates, which increase with the percentage by which output exceeds the quota, or differential rates which give preference to producers already operating at a high rate when the plan is introduced.

Because of the second consideration, the formulation of plans has frequently been difficult, and some provisions seem extremely complex. For example, investigation showed that the main bottleneck to increased plywood production was a relative shortage of peeler logs. The structure and practices of the lumber. industry make impossible a direct premium to loggers for increased production of peeler logs. Accordingly, plywood plants, which boosted output 25 per cent above quota were granted a premium of $\$ 7.5^{\circ}$ per thousand feet of logs for all peeler logs bought and consumed by those plants. This, of course, has had the direct effect of putting plywood plants in a preferential position in the peeler log market; and, indirectly, it has stimulated a general increase in the production of peeler logs. The best measure of the plan's success is the change in inventories' of peeler logs at plywood plants. During the first five months of 1946, the average monthly inventory of peeler logs was 70,415 thousand feet, log scale. In June, the first month of the premium payment plan, peeler logs inventories jumped to 93,043 thousand feet. This rate of increase has been sustained throughout the succeeding months. At the end of September, peeler log inventories were at a new all time high of 174,796 . October production of softwood plywood rose to 137 million square feet from r21 million in June.

Similarly the Southern hardwood flooring plan was to a large extent directed at giving hardwood flooring plants the financial means to secure a preferential buying position in the market for hardwood flooring. Within three months after the plan was introduced, production had increased by about 70 per cent.

The gypsum liner and merchant pig iron plans were aimed at subsidizing indus- 
tries which supply basic materials to building material producers. In the case of gypsum board and lath; the major obstacle to increased production has been an acute shortage of paper liner. Since paper liner was to a large extent provided to the gypsum industry by merchant paper producers, the plan pays premiums directly to producers of liner for increased production and shipment of liner to gypsum board and lath manufacturers. . Under this plan the gypsum industry received additional shipments of liner paper and reached new production records. Liner shipments from -non-integrated producers increased from 7,397 tons in May, the month prior to the introduction of the plan, to 10,166 tons in September.

Likewise, a prime bottleneck to increased production of many building items such as cast iron soil pipe and bathtubs was the over-all national shortage of foundry and malleable grades of pig iron. Accordingly, substantial premiums are being paid to. merchant pig iron producers for all pig iron production in excess of quota. During July and August monthly production of foundry and malleable grades of pig iron averaged about 470,000 net tons. The plan was introduced in September, and October production jumped to $5 \pi, 000$ net tons. This sizable increase is due primarily to the reopening of several closed furnaces. Further large increases in output are expected as more closed furnaces are brought back into blast under the stimulus of premium payments.

In the cast iron soil pipe industry the main obstacle to increased production was the extra expense involved in working more than five days a week. Accordingly, the premium payment plan was geared to provide the financial wherewithal to defray the additional costs of sixth day production. During the first seven months of 1946 the average monthly production of cast iron soil pipe was about 28,000 short tons. During August, the first month of operation under the premium payment plan, production went up to 35,796 short tons; in September, production further increased to 38,542; and in October, production reached the very satisfying level of 47,000. This increased output was partially due to allocation of pig iron to cast iron soil pipe producers. However, it is clear that even with adequate supplies of pig iron, current production levels could not have been reached without six days a week operations in soil pipe plants.

It is difficult to determine whether an industry subsidized with premium payments actually achieved greater production levels-and more quickly-than if no payments had been made; however, the increases in output of most materials following introduction of premium payment plans have been rapid, and it is clear that the premium payments have been a major factor in achieving this result.

(g) Many other types of action have been taken to increase output of materials such as:

(i) Assistance in settlement of strikes.

(ii) Assistance in importation of raw materials.

(iii) Construction of access roads into timberlands with funds secured for this purpose by NHA. 
(iv) Provision of technical facilities to the State of Washington to increase the availability of lumber from state-owned land.

Prospective Developments. There is no reason to expect that abandonment of price ceilings over building materials will have any effect whatsoever on the nonprice measures which have been taken to increase output. The extent to which price increases will be used as a device for increasing output is now the responsibility of the individual producers rather than the Office of Price Administration. Priorities assistance and other types of action by the CPA can continue under the Second War Powers Act until March 31, 1947. It is expected that some types of CPA assistance to building materials producers will be abandoned prior to that time because the liquidation of the Civilian Production Administration may start before the expiration of its legal powers. However, it may be necessary to continue some types of special assistance, in addition to premium payments, to materials producers after March 3I, 1947. If this appears necessary it is expected that the President will ask for a limited extension of the Second War Powers Act to provide the necessary authority.

\section{Materials Channeling.}

The general objective of the materials channeling system under the VEHP is to insure that the veterans housing gets first claim on the available supply of materials and products. It is impossible for VHP-I and reduction in federal construction to cut total demands for building materials down exactly to available supply. Even if over-all requirements for building materials were brought into rough balance with supply, there would still be shortages of individual materials in particular localities. Consequently, the present system of $H H$ priorities and set-asides will be necessary even when total building materials supplies are approximately equal to total demand in order to insure that housing contractors receive materials rapidly in preference to other users. Otherwise, continuity of construction would be interrupted by sporadic shortages of some items, and the low costs associated with efficiency could not be secured in the construction of veterans housing.

The following techniques are used to direct the flow of building materials into housing in preference to other types of construction:

(a) HH Priorities. A contractor may purchase materials for the construction of a housing project approved under VEHP using an $\mathrm{HH}$ priority rating which gives his orders preferred status in relation to non-rated orders. Under the terms of Priorities Regulation 33, a supplier of building materials must sell to a customer whose order is accompanied by an $\mathrm{HH}$ rating in preference to customers with unrated orders. The HH ratings have the same legal status as the priorities which were issued for war production purposes and other priority ratings which are currently issued to protect certain military and other essential programs. However, AAA ratings issued only in special emergencies, and MM ratings issued for limited procurement of supplies by the military agencies, take precedence over $\mathrm{HH}$ ratings. 
$\mathrm{HH}$ ratings may be used to purchase 66 materials listed on Priorities Regulation 33 for use in housing projects approved under VEHP. These materials include practically all those which have imposed serious limitations on housing construction.

$\mathrm{HH}$ ratings differ in one important respect from the preference ratings which were used during the war and from the AAA and MM preference ratings which are still used by military agencies for essential procurement. Generally speaking, HH ratings can be served only on the distributor of building materials. They cannot be extended back from the distributor to the producer for the replenishment of inventories. However, in some cases the normal distributive practices of the producers are not adequate to provide dealers with the supplies needed to meet $\mathrm{HH}$ ratings. Two types of action have been taken to meet this situation. In case of lumber, a CPA order specifies alternative methods by which lumber distributors may place certified orders on sawmills for replenishment of their lumber stocks. In the case of twelve scarce building materials, the Civilian Production Administration has found it necessary to make $\mathrm{HH}$ ratings extendable in varying degrees. $\mathrm{HH}$ ratings have been given a limited extendability for nails, steel pipe and certain fittings, and galvanized steel sheet to enable the dealer who has received an $\mathrm{HH}$ rating to use it in buying from his wholesaler. $\mathrm{HH}$ ratings have been made extenclable back to the manufacturer in the case of brick, structural clay tile and concrete blocks.

(b) Set-asides. In order to make $\mathrm{HH}$ ratings effective at the distributor level for particularly critical building materials, the Civilian Production Administration, at the request of the National Housing Agency, requires distributors to set aside a portion of their supply each month to meet $\mathrm{HH}$ rated orders. When a building material is in critically short supply there is great pressure on the distributors to meet the needs of their regular customers whether or not these customers are eligible to use an $\mathrm{HH}$ rating under the VEHP. If a dealer has no rated orders on his books when he receives a shipment of a scarce item he is legally entitled to do so in the absence of set-asides. Consequently, many building materials dealers decline to accept rated orders for critical materials when they have no stocks on hand so that they will not have rated orders on their books to interfere with "normal" distribution when new stocks are received. In order to compel distributors to accept rated orders, it has been necessary over a period of months to place over 20 especially scarce materials under set-aside regulations. Under the initial set-aside rules, a dealer who received a shipment of critical building materials was required to reserve part of it for a limited period-generally three weeks-to meet $\mathrm{HH}$ rated orders. After expiration of the period, he was free to sell on unrated orders. Leakages of set-aside materials to non-housing uses were so serious that the automatic termination of set-asides has been revoked for most reserved materials. Now a dealer is required to hold a fixed percentage of his receipts indefinitely to fill $\mathrm{HH}$ and other priority orders. If he does not receive priority orders up to the amount of his set-aside over a period of months, he may appeal to the NHA for release from set-aside rules.

The set-asides range from approximately 60 to 100 per cent. For example, 60 
per cent of water heaters must be set aside to meet rated orders. For metal doors and frames set-asides are 75 per cent; on floor and wall furnaces 95 per cent; on prefabricated houses roo per cent. Other materials under set-asides include bathtubs, certain sizes of copper tubing, cast iron soil pipe, clay sewer pipe, hardwood flooring, millwork, etc.

(c) Other materials-channeling actions which have been taken by the Civilian Production Administration at the request of the National Housing Agency include:

(i) Issuance of regulations to insure that certain types of logs and raw lumber are used in specified amounts for the production of critically short lumber products. For example, a CPA order diverts supplies of certain hardwoods into flooring, and certain grades of the western softwoods into millwork.

(ii) At the request of the National Housing Agency, the Civilian Production Administration has issued a conservation order on cast iron pipe which prohibits its use more than five feet beyond the foundation of a building, except under special circumstances. The objective of this order is to insure that the available supply of cast iron soil pipe is used for essential interior purposes. The order in effect requires that cast iron soil pipe substitutes be used where great durability, resistance to stress, and permanence are not essential.

Consequences of Price Decontrol. The effects of price decontrol on materials channeling are not clear as of November 15 when this article is being written. Channeling rules may be subject to additional strain now that buyers of building materials are legally free to pay exorbitant prices to get materials they are not entitled to receive under priorities and set-aside rules. On the other hand it is clear that such behavior was already widespread prior to November 9 . There are many cynics who say that the situation must remain stable or improve because it could get no worse.

Some officials argue that termination of unpopular price controls will improve cooperation with priorities and set-aside regulations and ease enforcement problems. Others believe that the channeling controls have been seriously weakened and must be progressively modified because they are now isolated and under attack from all sides by the same forces which have compelled general price decontrol.

\section{Industrialized Housing.}

The Housing Expediter has launched a major effort to create a new industry in the United States. The theoretical advantages of applying industrialized mass production techniques to housing construction are great because of the expected savings in materials and labor costs, and the potential improvement in quality of construction. For these reasons it is expected that the output of the prefabricated housing industry will exert a stabilizing influence on rocketing construction costs. Furthermore, the construction capacity of the conventional building industry is already taxed. The output of the prefabricated industry is expected to be a significant con- 
tribution during 1947 over and above that which can be expected from the conventional housing industry.

During 1946 the Housing Expediter had expected that the prefabricated industry would start approximately roo,000 units. Because of serious delays in developing plans, and procurement of machinery and materials, the number of starts will be considerably less than half this number. However, the Housing Expediter is launching an industrialized housing program for 1947 which is expected to result in the starting of about 300,000 prefabricated houses. As of November 15, the original I 947 goal of 600,000 prefabs appeared definitely out of the question because of materials and facilities shortages.

In addition to frame, plywood, and stressed skin prefabricated construction, the Expediter hopes that a large number of metal prefabricated houses will be built, divided about half and half between steel and aluminum.

The major means available to the Expediter for developing a prefabricated industry is his authority to enter into guaranteed market agreements. Under the terms of the Patman Act, the Expediter may use the powers of the Reconstruction Finance Corporation Act to underwrite guaranteed markets for prefabricated houses provided that at no time the number of prefabricated houses covered by the outstanding underwriting agreements exceeds 200,000. By transferring the risk to the Federal Government, prefabricators are relatively free to proceed with the technical and production aspects of applying industrial techniques to housing construction on a mass production basis. By the end of October, 1946, guaranteed market contracts had already been signed for the production of approximately 30,000 prefabricated houses in 1947 .

At the present time the Expediter is assisting several prospective prouncers of prefabricated houses in negotiating with the War Assets Administration for surplus plants, and with the Reconstruction Finance Corporation for financial assistance to start production.

\section{Rental Houses.}

Veterans have indicated a strong preference for rental housing as opposed to sale houses in several surveys conducted under the auspices of the National Housing Agency. In view of the current price situation, veterans prefer not to invest their limited resources in the purchase of a house at a price which they cannot realize on resale in the future. At a time when the prices of old houses are inflated above prewar values and when building costs on new houses are far above pre-war levels, a prudent veteran with limited financial resources prefers to rent. Some veterans have protested vigorously that it is worse than ironical for the Government to give veterans a preference in purchasing new houses at prices which are considerably above the probable resale value in $\mathbf{1 9 5 0}$.

Under these circumstances, one of the objectives of the VEHP is to secure 2 large volume of rental construction. During 1946 this. effort met with some success 
because practically all conversions were designed for rent rather than sale, and all government temporary re-use construction was for rent. However, these two categories totalled only about one quarter of the program. Of new permanent housing started between 20 and 25 per cent was intended for rent. Unfortunately, it is expected that there will be only a small re-use program and few conversions in 1947. If the 1946 ratio of sale to rental housing continues into 1947 , approximately 75 per cent of the starts by private construction industry will be for sale.

Strong preference among builders for speculative construction of houses for quick sale as opposed to investment in rental housing is based upon uncertainty with respect to future cost trends. No builder and no investor wishes to put money into a rental house now which can be duplicated at a significantly lower cost in the near future. Investors prefer hard money during inflation because they do not want to invest in real property which will depreciate in value with a break in prices. Under these circumstances, large scale construction of apartments and rental housing developments is not feasible without some form of government assistance which will reduce financial or construction costs by almost the amount of the anticipated reduction in construction costs when prices break at the end of the inflationary period.

\section{Major Policy Problems.}

At the present time the Housing Expediter has a series of major policy problems which may or may not have solutions. They are as follows:

(a) Falling off in housing starts. During the latter part of 1946 there was a slow decline in the number of housing starts. It is expected that the number of starts per month immediately following price decontrol may collapse far below the August, September and October level. There was a decline in housing starts during the third quarter of 1946 . This was due primarily to shortages of materials which were in part rectified by drastic increases in set-asides and rapidly increasing output under the premium payments plan. There may be a further sharp drop in new housing starts below the normal seasonal decline. due primarily to uncertainty with respect to costs. This is a further obstacle to VEHP about which the Expediter can do nothing directly.

The extent to which housing starts will pick up during early 1947 depends upon the extent to which surpluses of building materials force stabilization or decline in prices. Long before prices of building materials decline building materials producers will probably exert enormous pressure toward relaxing VHP-I in an effort to regenerate industrial and commercial construction demand which would tend to hold building materials prices at inflated levels.

Clearly the 1947 program of $\mathrm{I} .5$ starts must be reduced. The extent to which it will be slashed is as yet undeterminable.

(b) Rental houses. Even before price decontrol veterans were becoming more 
reluctant to buy new homes at inflated prices. Large scale rental housing which does not require a veteran to invest in inflated real estate and which is more economical to build than individual detached houses offers a solution to many of the Expediter's dilemmas. Under the terms of existing legislation it may be possible for the Expediter to make limited financial concessions in the form of lower interest rates or long amortization periods which would tend to stimulate rental construction. It might also be possible for him to use his channeling authority as materials become more plentiful to insure the continuity of materials flow to rental projects with consequent savings in construction costs. However, until building materials and labor costs go down significantly, it is probable that only a more substantial assumption of risk by the Government, based on the present RFC powers and new legislation, would induce large scale investors to undertake rental housing developments.

(c) Political support. In order to start a record volume of houses next year, it is imperative that channeling of pig iron, steel, lumber and other materials into housing and housing products be continued. This means depriving powerful and local industries of materials which they will do their utmost to secure. It is equally imperative, and equally difficult, to continue restricttions on non-residential construction.

Without the vigorous support of veterans who need houses, and the large number of relatively small industries which benefit from the VEHP, the National Housing Agency cannot stand alone in a hurricane of decontrol and maintain its present distribution orders by means of which housing secures essential supplies of basic materials. Decontrol psychology and industry pressures are too strong. Bureaucrats should not, cannot, and do not wish to try to carry out a program which lacks popular support.

Under these circumstances, it is inevitably up to Congress, or the President (preferably both), to make a decision between housing for veterans and durable goods for those who have money with which to buy. The decision may depend on which alternative the representatives and servants of the people think they hear people clamoring for. Some kinds of people, little people, have to clamor louder than others to be heard. 